\title{
Antioxidant and antitumor activities of water extracts from the root of Actinidia kolomikta
}

\author{
DI GUAN ${ }^{1}$, ZHENYA ZHANG $^{1}$, YINGNAN YANG ${ }^{1}$, NORIO SUGIURA ${ }^{1}$, HONGHAI HU $^{3}$, \\ GUOQING XING ${ }^{1}$, JIQIANG LIU ${ }^{2}$, XIAOYAN ZU ${ }^{1}$ and YING ZHANG ${ }^{1}$ \\ ${ }^{1}$ Graduate School of Life and Environmental Sciences, University of Tsukuba; ${ }^{2}$ Biological Clock Research Group, \\ Biomedical Research Institute, Advanced Industrial Science and Technology, Tsukuba; \\ ${ }^{3}$ Department of Food Sciences, Ishikawa Prefectural University, Ishikawa, Japan
}

Received September 8, 2010; Accepted November 1, 2010

DOI: $10.3892 / \mathrm{etm} .2010 .163$

\begin{abstract}
The genus of Actinidia is widely distributed throughout the Asian continent. Specific Actinidia species have been used as health foods and medical products for cancer treatment. Actinidia kolomikta is a species of wild plant that grows in the northern part of Indochina. However, few studies on its bioactivity have been reported. In this study, the polysaccharide and polyphenol contents, the SOD-like activity and the DPPH radical-scavenging activity of water extracts from the root of Actinidia kolomikta produced under different extraction temperatures were investigated. Furthermore, the water extraction-ethanol precipitate (WE-EP) fraction and the water extraction-ethanol supernatant (WE-ES) fraction were used to test the anti-proliferative action on DLD-1 colon cancer cells. Extracts produced using the $100^{\circ} \mathrm{C}$ extraction procedure revealed higher extraction yields and antioxidant activities than extracts produced using the $40^{\circ} \mathrm{C}$ extraction procedure. The WE-EP and WE-ES fractions exhibited anti-proliferative effects on the DLD-1 cells. Moreover, the WE-ES polyphenolenriched fraction possessed more potent anti-proliferative effects on the DLD-1 cells by inducing apoptosis compared to the WE-EP polysaccharide fraction. Medicinal plant extracts are generally considered to be relatively non-toxic at low doses and are not thought to cause major side effects compared to those observed with drugs. Wild A. kolomikta may provide an alternative to currently employed cancer therapies, and may be used as a natural health food with antioxidant actions.
\end{abstract}

\section{Introduction}

Oxidation is an essential biological process for energy production in numerous living organisms. However, exces-

Correspondence to: Dr Zhenya Zhang, Graduate School of Life and Environmental Sciences, University of Tsukuba, 1-1-1 Tennodai, Tsukuba 305-8577, Ibaraki, Japan

E-mail: tyou6688@sakura.cc.tsukuba.ac.jp

Key words: antioxidant activity, DLD-1 cells, anti-proliferation, apoptosis sive reactive oxygen species (ROS) produced in vivo during certain oxidative reactions are strongly associated with the etiology and/or progression of a number of diseases, such as atherosclerosis, cancer and other degenerative diseases, and in aging (1-4). Recently, an increasing number of studies confirm that numerous fruits and vegetables may afford protection against certain chronic diseases caused by oxidative stress since they contain a wide variety of free radical scavenging molecules, such as polyphenols and flavonoids, Vitamin C, carotenoids and tocopherols $(5,6)$, which scavenge radicals by inhibiting initiation and breaking the chain propagation or by suppressing the formation of free radicals by binding to metal ions, reducing hydrogen peroxide and quenching superoxide and singlet oxygen. Thus, these phytochemicals play an important role in the prevention of these diseases (7).

The genus Actinidia consists of over fifty-eight species widely distributed throughout the Asian continent. Specific Actinidia species, such as A. arguta and A. chinensis Planch, are used as health foods and medical agents for cancer treatment (8). It has also been reported that the root of A. eriantha possesses antitumor and immunomodulatory activity $(9,10)$.

Actinidia kolomikta, which grows in the wild throughout the northern part of Indochina, is a locally famous traditional medicine for diabetes. However, there are few studies concerning its bioactivity. The purpose of this study was to investigate the antioxidant and antitumor activity of the vine root extracts processed at high and low water extraction temperatures.

\section{Materials and methods}

Chemicals and reagents. 2,2-Diphenyl-1-picryl-hydrazyl (DPPH), Folin-Ciocalteu reagent, 6-hydroxy-2,5,7,8tetramethylchroman-2-carboxylic acid (Trolox), propidium iodide (PI), RPMI-1640 medium, fetal bovine serum (FBS) and penicillin-streptomycin solution were purchased from Sigma-Aldrich, Inc. (St. Louis, MO, USA). The SOD assay kit-WST, Cell counting kit-8 and Hoechst 33258 solution were purchased from Dojindo Molecular Technologies, Inc. (Kumamoto, Japan). Gallic acid was purchased from Nacalai Tesque, Inc. (Kyoto, Japan). 


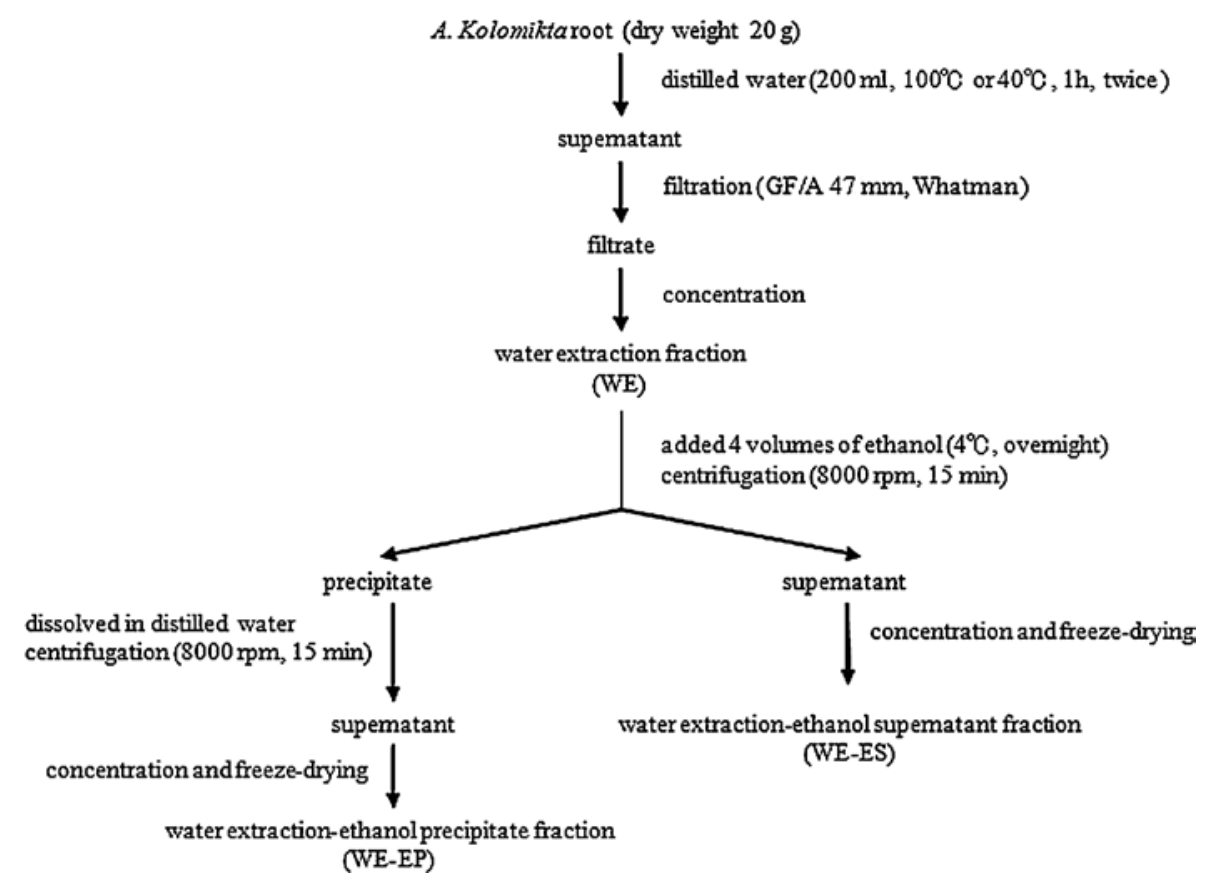

Figure 1. Scheme of the water extraction procedure applied to the root of A. kolomikta.

Cell line and culture. The DLD-1 human colon cancer cell line was obtained from the Cell Resource Center for Biomedical Research, Aging and Cancer, Tohoku University, Japan. It was grown in RPMI-1640 medium containing 10\% FBS and $1 \%$ penicillin/streptomycin. The culture was maintained at $37^{\circ} \mathrm{C}$ in a humidified $5 \% \mathrm{CO}_{2}$ atmosphere (ESPEC $\mathrm{CO}_{2}$ Incubator). The cells were cultured for 2-3 days to reach the logarithmic phase and were then used for the experiment.

Plant material and preparation. The roots of Actinidia kolomikta were collected from the northern part of Indochina. The scheme of the extraction procedure is presented in Fig. 1. For the high temperature extraction, the roots were extracted with distilled water at $100^{\circ} \mathrm{C}$ for $1 \mathrm{~h}$ at a ratio of 1:10 (w/v). The operation was repeated twice. The aqueous extract was centrifuged at 6,000 rpm for $15 \mathrm{~min}$ and filtered through a filter paper (GF/A, $47 \mathrm{~mm}$; Whatman, UK). The filtrate was concentrated and lyophilized to obtain the water extraction (WE) fraction. The WE fraction was redissolved in distilled water and was added to four volumes of $99.5 \%$ ethanol and then stored at $4{ }^{\circ} \mathrm{C}$ overnight for precipitation. The precipitate and supernatant were separated and collected by centrifugation at $8,000 \mathrm{rpm}$ for $15 \mathrm{~min}$. The supernatant was concentrated and lyophilized to obtain the water extractionethanol supernatant (WE-ES) fraction. The precipitate was washed with $80 \%$ ethanol and dissolved in distilled water. After the centrifugation, the supernatant was concentrated and lyophilized to obtain the water extraction-ethanol precipitate (WE-EP) fraction.

The low temperature extraction operation was the same as the high temperature treatment, but distilled water at $40^{\circ} \mathrm{C}$ was used.

Determination of total carbohydrates and polyphenols. The content of total carbohydrates in the extracts was determined by the phenol-sulfuric acid method $(11,12)$, with glucose as a standard. First, $1 \mathrm{ml}$ of the extraction fraction was collected in glass tubes and $1 \mathrm{ml}$ of $5 \%$ phenol solution and $5 \mathrm{ml}$ of concentrated sulphuric acid were added. After mixing for $2 \mathrm{~min}$ at room temperature, the tubes were boiled at $100^{\circ} \mathrm{C}$ for $15 \mathrm{~min}$ in a hot water bath. Subsequently, the absorbance was read at $486 \mathrm{~nm}$ with a spectrophotometer (HACH, DR/4000 U).

The total polyphenol content was determined using the Folin-Ciocalteu method (3). A volume of $7.9 \mathrm{ml}$ distilled water, $0.1 \mathrm{ml}$ extract fraction and $0.5 \mathrm{ml}$ Folin-Ciocalteu reagent (1:1 with distilled water) were added and mixed in a tube for $1 \mathrm{~min}$. Then, $1.5 \mathrm{ml}$ of sodium carbonate $(20 \mathrm{~g} / 100 \mathrm{ml})$ was added, mixed and allowed to stand for $2 \mathrm{~h}$ at room temperature in the dark. The absorbance was read at $765 \mathrm{~nm}$. The total polyphenol content was determined using gallic acid as a standard.

SOD-like activity assay. The levels of SOD-like activity in the extracts were measured using the SOD assay kit-WST according to the technical manual provided by Dojindo Molecular Technologies. Briefly, in a 96-well plate, sample solution $(20 \mu 1)$ was added to each sample and blank 2-well, and $20 \mu \mathrm{l}$ double-distilled water was added to each blank 1and blank 3-well. Then, $200 \mu \mathrm{l}$ of WST working solution was added to each well. After mixing, $20 \mu \mathrm{l}$ of dilution buffer was added to each blank 2- and blank 3-well, and $20 \mu$ l of enzyme working solution was added to each sample- and blank 1-well. The plate was incubated at $37^{\circ} \mathrm{C}$ for $20 \mathrm{~min}$, and the optical density (OD) was determined at $450 \mathrm{~nm}$, using a microplate reader (Model 550; BioRad, USA). The SOD-like activity was calculated using the following equation: SOD activity (inhibition rate $\%)=\left\{\left[\left(\mathrm{A}_{\text {blank1 }}-\mathrm{A}_{\text {blank3 }}\right)-\left(\mathrm{A}_{\text {sample }}-\mathrm{A}_{\text {blank2 }}\right)\right] /\left(\mathrm{A}_{\text {blank } 1^{-}}\right.\right.$ $\left.\left.\mathrm{A}_{\text {blank3 }}\right)\right\} \times 100$.

$\mathrm{A}_{\text {blank } 1}, \mathrm{~A}_{\text {blank2 }}, \mathrm{A}_{\text {blank3 } 3}$ and $\mathrm{A}_{\text {sample }}$ are the absorbances of blank 1-, blank 2-, blank 3- and sample-wells. The SOD 


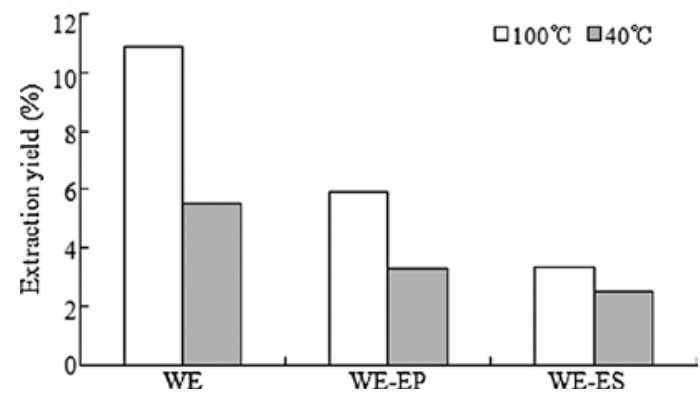

Figure 2. Extraction yields of the extracts from the root of A. kolomikta.

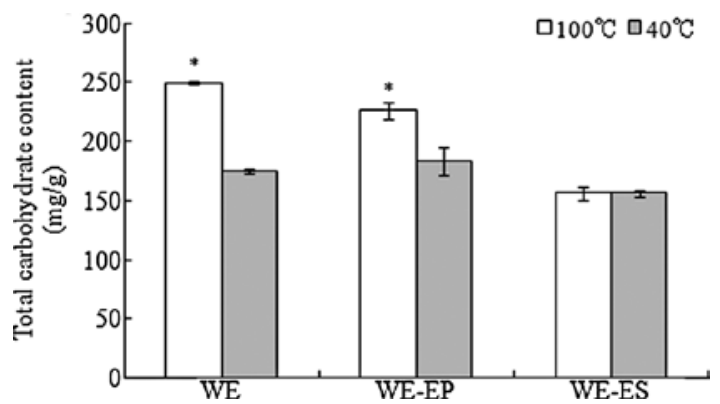

Figure 3. Total carbohydrate contents of the extracts from the root of A. kolomikta. Data are expressed as the mean $\pm \mathrm{SD}$ of triplicate determinations $\left(* \mathrm{p}<0.05\right.$ compared to extraction at $\left.40^{\circ} \mathrm{C}\right)$.

activity ( 1 unit) was defined as the amount of enzyme having a 50\% inhibitory effect on WST-1.

Measurement of the DPPH scavenging activity. The DPPH scavenging activity was measured according to Nakajima et al (13) and Yang et al (14). Volumes of $80 \mu 1$ of $0.5 \mathrm{mM}$ DPPH in $\mathrm{MeOH}$ solutions and $80 \mu 1$ of $0.1 \mathrm{M}$ MES buffer in 50\% $\mathrm{MeOH}$ (pH 6.0) were added to a 96-well plate, and an aliquot of sample solution was added for a total volume of $200 \mu 1$. After $10 \mathrm{~min}$ of reaction, the OD was measured at $570 \mathrm{~nm}$ with a microplate reader. The DPPH radical-scavenging activity was calculated using the following equation: DPPHscavenging activity $(\%)=\left(1-\mathrm{A}_{\text {sample }} / \mathrm{A}_{\text {control }}\right) \times 100$.

The scavenging activity of the sample is expressed as a $50 \%$ effective concentration $\left(\mathrm{EC}_{50}\right)$, which represents the sample concentration $(\mu \mathrm{g} / \mathrm{ml})$ inhibiting $50 \%$ of the DPPH radical activity.

Cell proliferation assay. The DLD-1 cells were grown in RPMI-1640 medium at $37^{\circ} \mathrm{C}$ in a $5 \% \mathrm{CO}_{2}$ atmosphere to logarithmic phase. The cells were harvested, and an aliquot $(100 \mu \mathrm{l})$ of the DLD-1 cell suspension $\left(5 \times 10^{4}\right.$ cells $\left./ \mathrm{ml}\right)$ was dispensed into a 96-well plate and pre-incubated at $37^{\circ} \mathrm{C}$ in a $5 \% \mathrm{CO}_{2}$ atmosphere for $24 \mathrm{~h}$. The cells were then exposed to various concentrations $(25,50,100,200$ and $400 \mu \mathrm{g} / \mathrm{ml})$ of the extracts for 12, 24 and $48 \mathrm{~h}$. After drug exposure, $10 \mu \mathrm{l}$ of Cell Counting reagent solution was added, and incubation was carried out at $37^{\circ} \mathrm{C}$ for $4 \mathrm{~h}$. The cell numbers were quantitated by reading the $\mathrm{OD}$ at $450 \mathrm{~nm}$.

Flow cytometric assay. The flow cytometric assay was performed according to Zhang et al (15) with some modifica-

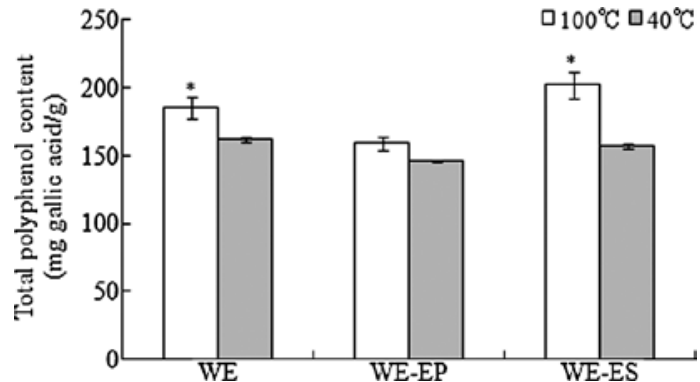

Figure 4. Total polyphenol contents of the extracts from the root of A. kolomikta. Data are expressed as the mean $\pm \mathrm{SD}$ of triplicate determinations $\left({ }^{*} \mathrm{p}<0.05\right.$ compared to extraction at $\left.40^{\circ} \mathrm{C}\right)$.

tions. DLD- 1 cells $\left(1 \times 10^{5}\right.$ cells $\left./ \mathrm{ml}\right)$ were incubated in a 6-well plate with the extracts at concentrations of 25 and $100 \mu \mathrm{g} /$ $\mathrm{ml}$ for $48 \mathrm{~h}$. The cells were harvested and washed with cold PBS (-) and then fixed in $70 \%$ ethanol at $4^{\circ} \mathrm{C}$ for $4 \mathrm{~h}$. Cells were strained with PI solution $(20 \mu \mathrm{g} / \mathrm{ml})$ at $4^{\circ} \mathrm{C}$ for $30 \mathrm{~min}$. DNA histograms were generated by flow cytometry (BD LSR; BD Biosciences). Data from 10,000 cells per sample were collected, and the percentage of apoptotic cells was obtained with the CellQuest software (Becton Dickinson).

Nuclear morphological observation. DLD-1 cells $\left(1 \times 10^{5} / \mathrm{ml}\right)$ were incubated in 6-well plate with the extracts at concentrations of 25 and $100 \mu \mathrm{g} / \mathrm{ml}$ for $48 \mathrm{~h}$. The cells were subsequently harvested and stained with Hoechst $33258(10 \mu \mathrm{g} / \mathrm{ml})$ for $10 \mathrm{~min}$. Nuclear morphological changes were observed using a Leica fluorescence microscope.

Statistical analysis. Experiments were conducted in triplicate, and the results were expressed as the mean \pm SD. Statistical significance was calculated by a two-tailed Student's t-test (16). $p<0.05$ was considered significant.

\section{Results}

Extraction yield and total polysaccharide and polyphenol contents. The extraction yields are shown in Fig. 2. Yields of WE, WE-EP and WE-ES produced using the $100^{\circ} \mathrm{C}$ procedure were $10.9,5.89$ and $3.35 \%$, while the yields of the fractions produced using the $40^{\circ} \mathrm{C}$ procedure reached only $5.53,3.28$ and $2.5 \%$. Thus, the extraction yields produced using the $100^{\circ} \mathrm{C}$ procedure were higher than those produced using the $40^{\circ} \mathrm{C}$ extraction procedure.

The total carbohydrate contents are shown in Fig. 3. The total carbohydrate contents of the WE and WE-EP fractions produced using the $100^{\circ} \mathrm{C}$ extraction procedure were 249.6 and $226.6 \mathrm{mg} / \mathrm{g}$, respectively, which were significantly higher than the total carbohydrate contents of WE $(175.1 \mathrm{mg} / \mathrm{g})$ and WE-EP $(183.0 \mathrm{mg} / \mathrm{g})$ produced using the $40^{\circ} \mathrm{C}$ extraction procedure. The results also revealed that the total carbohydrate content in the WE-EP fraction was higher than that in the WE-ES fraction.

The total polyphenol contents are shown in Fig. 4. The polyphenol contents of the WE, WE-EP and WE-ES fractions produced using the $100^{\circ} \mathrm{C}$ extraction procedure were higher than the polyphenol contents of the fractions produced using 


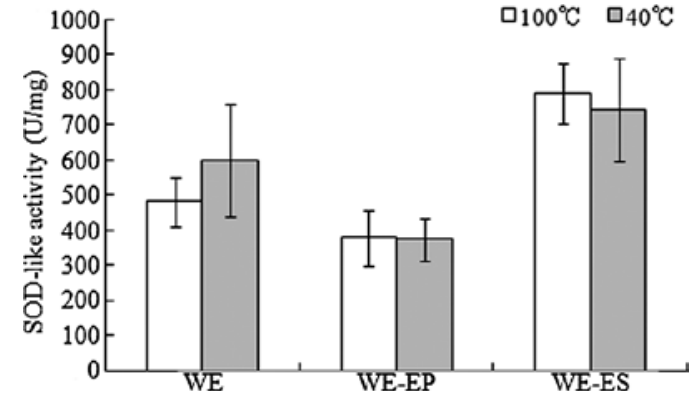

Figure 5. SOD-like activity of extracts from the root of A. kolomikta. Data are expressed as the mean $\pm \mathrm{SD}$ of triplicate determinations.

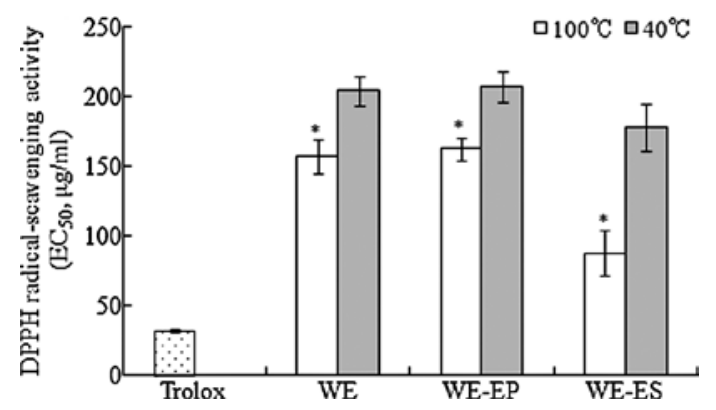

Figure 6. DPPH radical-scavenging activity of extracts from the root of A. kolomikta. Data are expressed as the mean $\pm \mathrm{SD}$ of triplicate determinations. ( $\mathrm{p}<0.05$ compared to extraction at $\left.40^{\circ} \mathrm{C}\right)$.

$40^{\circ} \mathrm{C}$. Moreover, the polyphenol contents of WE and WE-ES produced using the $100^{\circ} \mathrm{C}$ extraction procedure were significantly higher than those of the extracts produced using the $40^{\circ} \mathrm{C}$ extraction procedure $(\mathrm{p}<0.05)$. The polyphenol content of the WE-ES fraction was higher than that of WE-EP. Data revealed that the polyphenol content of WE-ES produced using the $100^{\circ} \mathrm{C}$ treatment consisted of $201.9 \mathrm{mg}$ gallic acid $/ \mathrm{g}$, which was the highest content compared to all of the other fractions.

SOD-like activity. As shown in Fig. 5, compared to the WE and WE-EP fractions, the WE-ES fraction exhibited a higher antioxidant activity; the SOD-like activities of the WE-ES fraction produced using the $100^{\circ} \mathrm{C}$ and $40^{\circ} \mathrm{C}$ extraction procedures were 790.3 and $742.6 \mathrm{U} / \mathrm{mg}$, respectively, while the WE-EP fraction exhibited the lowest SOD-like activities (377.9 and $374.1 \mathrm{U} / \mathrm{mg}$, respectively, for the WE-EP fractions produced using the $100^{\circ} \mathrm{C}$ and $40^{\circ} \mathrm{C}$ extraction procedures).

DPPH radical-scavenging activity. The DPPH radicalscavenging activity is shown in Fig. 6. The positive control Trolox revealed the strongest DPPH radical-scavenging activity $\left(\mathrm{EC}_{50}, 31.7 \mu \mathrm{g} / \mathrm{ml}\right)$, and the WE-ES fraction produced using the $100^{\circ} \mathrm{C}$ extraction procedure had the second strongest radical-scavenging activity $\left(\mathrm{EC}_{50}, 87.4 \mu \mathrm{g} / \mathrm{ml}\right)$. Moreover, all of the fractions (WE, WE-EP and WE-ES) produced using the $100^{\circ} \mathrm{C}$ extraction procedure revealed significant higher DPPD radical-scavenging activities compared to the fractions produced at $40^{\circ} \mathrm{C}(\mathrm{p}<0.05)$.

Anti-proliferative effects on DLD-1 cells. The WE-EP and WE-ES fractions were used for the experiment of antiproliferation on the DLD-1 cells (Fig. 7). In this experiment, the extracts at various concentrations $(25,50,100,200$ and $400 \mu \mathrm{g} / \mathrm{ml})$ were used. The results revealed that, the higher the concentration of the extract, the lower the cell survival rate. Treatment at the concentration of $400 \mu \mathrm{g} / \mathrm{ml}$ revealed the strongest inhibitory effect on the DLD-1 cells. This suggests that the WE-EP and WE-ES fractions (produced using the $100^{\circ} \mathrm{C}$ and $40^{\circ} \mathrm{C}$ extraction procedures) exhibited anti-prolif-
A

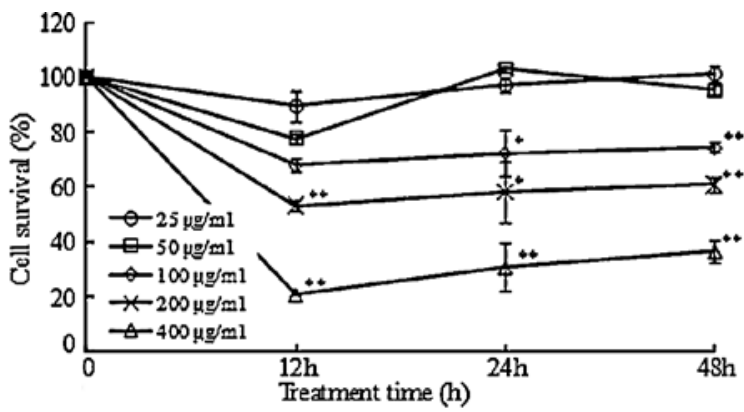

C

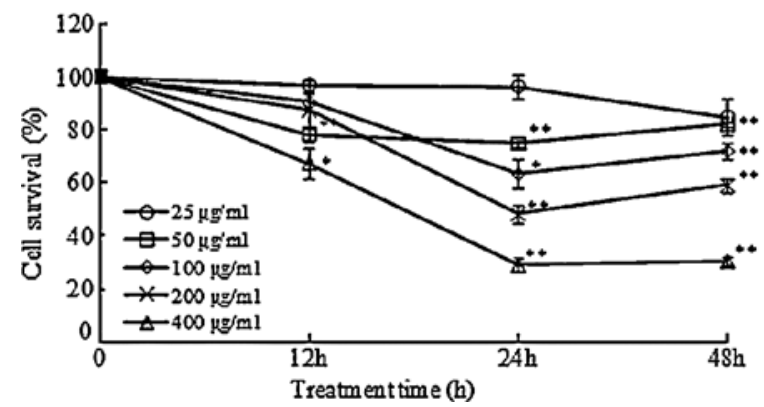

B

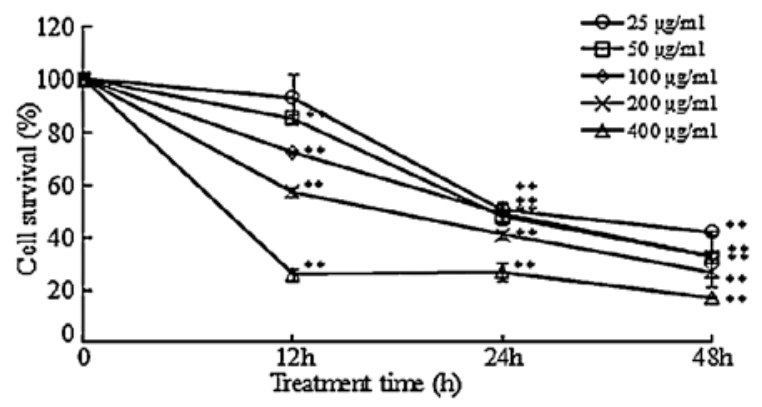

D

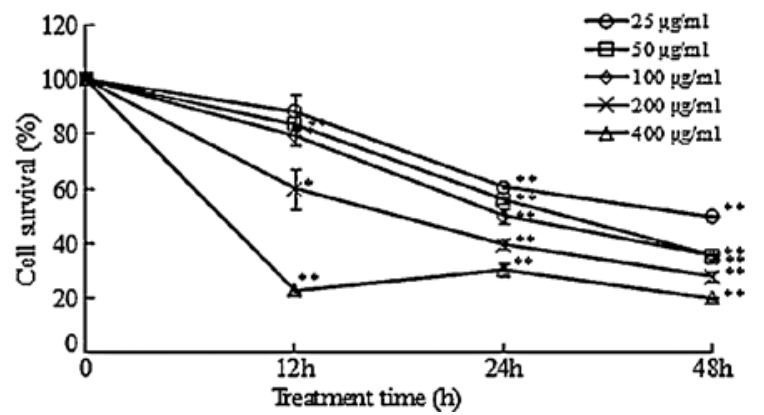

Figure 7. Anti-proliferative effect of A. kolomikta extracts on DLD-1 cell. (A) WE-EP and (B) WE-ES fractions produced using the $100^{\circ} \mathrm{C}$ extraction procedure; (C) WE-EP and (D) WE-ES fractions produced using the $40^{\circ} \mathrm{C}$ extraction procedure. Data are expressed as the mean $\pm \mathrm{SD}$ of three independent experiments. $\left(\right.$ p $<0.05,{ }^{* *} \mathrm{p}<0.01$ compared to the control). 

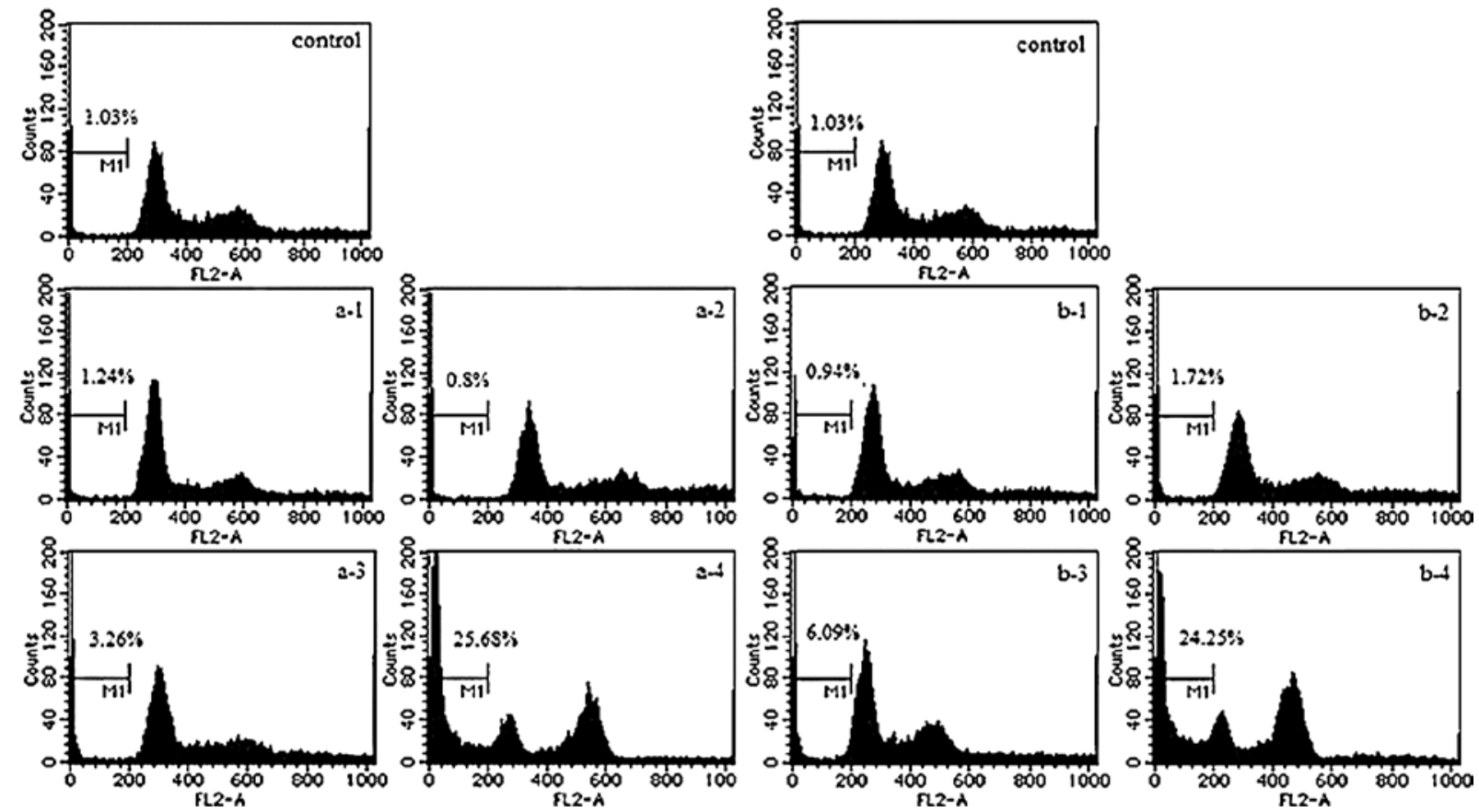

Figure 8. The percentage of apoptosis of DLD-1 cancer cells treated with A. kolomikta extracts. DLD-1 cells were incubated for 48 h with WE-EP and WE-ES. Extracts were produced using (a) $100^{\circ} \mathrm{C}$ and (b) $40^{\circ} \mathrm{C}$ extraction procedures; (a-1, a-2, b-1 and b-2) treated with WE-EP; (a-3, a-4, b-3 and b-4) treated with WE-ES; (a-1, a-3, b-1 and b-3) treated with a $25 \mu \mathrm{g} / \mathrm{ml}$ concentration; ( a-2, a-4, b-2 and b4) treated with a $100 \mu \mathrm{g} / \mathrm{ml}$ concentration.

erative effects on DLD-1 cells in a dose-dependent manner. Moreover, the WE-ES fraction inhibited DLD-1 cell proliferation in a time-dependent manner, compared to WE-EP, for which a slight recovery of DLD-1 cell proliferation at $48 \mathrm{~h}$ was noted. When DLD-1 cells were treated with the WE-EP and WE-ES fractions for $12 \mathrm{~h}$, a decrease in DLD- 1 cell proliferation was noted. However, after the 48-h treatment, the cell survival rates increased in the DLD- 1 cells exposed to WE-EP. For example, when the DLD-1 cells were treated with the extracts at the concentration of $400 \mu \mathrm{g} / \mathrm{ml}$ for $24 \mathrm{~h}$, the cell survival rates induced by WE-EP and WE-ES (produced using the $100^{\circ} \mathrm{C}$ extraction procedure) were 30.7 and $27.0 \%$, respectively. At 48 h, the cell survival rates were 36.5 and $17.35 \%$, respectively. The same trend was observed when cells were treated with fractions produced using the $40^{\circ} \mathrm{C}$ extraction procedure. Based on these results, the anti-proliferative effect of the WE-ES fraction was stronger than that of WE-EP.

Apoptosis assay. Results of the apoptosis assay are shown in Fig. 8. When the DLD-1 cells were treated with the WE-EP fraction (produced using the $100^{\circ} \mathrm{C}$ extraction procedure) at concentrations of 25 and $100 \mu \mathrm{g} / \mathrm{ml}$ for $48 \mathrm{~h}$, the percentage of apoptotic cells decreased from 1.24 to $0.8 \%$ while the percentage increased from 0.94 to $1.72 \%$ upon treatment of WE-EP produced using the $40^{\circ} \mathrm{C}$ extraction procedure). These data did not reveal a significant increase. In comparison with the WE-EP treatment, when DLD-1 cells were exposed to WE-ES (produced using the $100^{\circ} \mathrm{C}$ extraction procedure) at concentrations of 25 and $100 \mu \mathrm{g} / \mathrm{ml}$ for $48 \mathrm{~h}$, the percentage of apoptotic cells increased from 3.26 to $25.68 \%$ while the percentage of apoptotic cells increased from 6.09 to $24.25 \%$ when treated with WE-ES produced at $40^{\circ} \mathrm{C}$. This suggests that WE-ES induces DLD-1 cell apoptosis in a dose-dependent manner.
Changes in apoptotic cell morphology. The criteria used to identify pro-apoptosis includes nuclear shrinkage and chromatin condensation (17). As shown in Fig. 9, nuclear fragmentation was clearly noted when the DLD-1 cells were exposed to WE-ES (25 and $100 \mu \mathrm{g} / \mathrm{ml}$ ) for $48 \mathrm{~h}$, while upon treatment with WE-EP at 25 and $100 \mu \mathrm{g} / \mathrm{ml}$ for $48 \mathrm{~h}$, apoptotic cells were hardly observed.

\section{Discussion}

The extraction yields and the polysaccharide and polyphenol contents of the extracts produced using the $100^{\circ} \mathrm{C}$ procedure were higher than those of the extracts produced using the $40^{\circ} \mathrm{C}$ treatment. The total carbohydrate content of the WE-EP fraction was significantly higher than that of the WE-ES fraction. Since polysaccharides do not dissolve in $80 \%$ ethanol, WE-EP can be considered as a crude polysaccharide fraction. However, based on the results (Fig. 4), the WE-EP fraction still contained a certain amount of polyphenols. On the other hand, the polyphenol content of the WE-ES fraction was higher than that of WE-EP, but there were also some polysaccharides in the WE-ES fraction. Thus, crude polysaccharides were mostly contained in the WE-EP fraction, while in the WE-ES fraction, the polyphenol content was marked. Plant polysaccharides and polyphenols are antioxidants (18), and they scavenge radicals by inhibiting initiation and breaking chain propagation by suppressing formation of free radicals by binding to metal ions, reducing hydrogen peroxide and quenching superoxide and singlet oxygen. In this study, the WE-EP and WE-ES fractions exhibited SOD-like activity and DPPH radical-scavenging activity, while the WE-ES fraction revealed higher antioxidant activity than WE-EP. It has been reported that polyphenols are strong radical scavengers and 

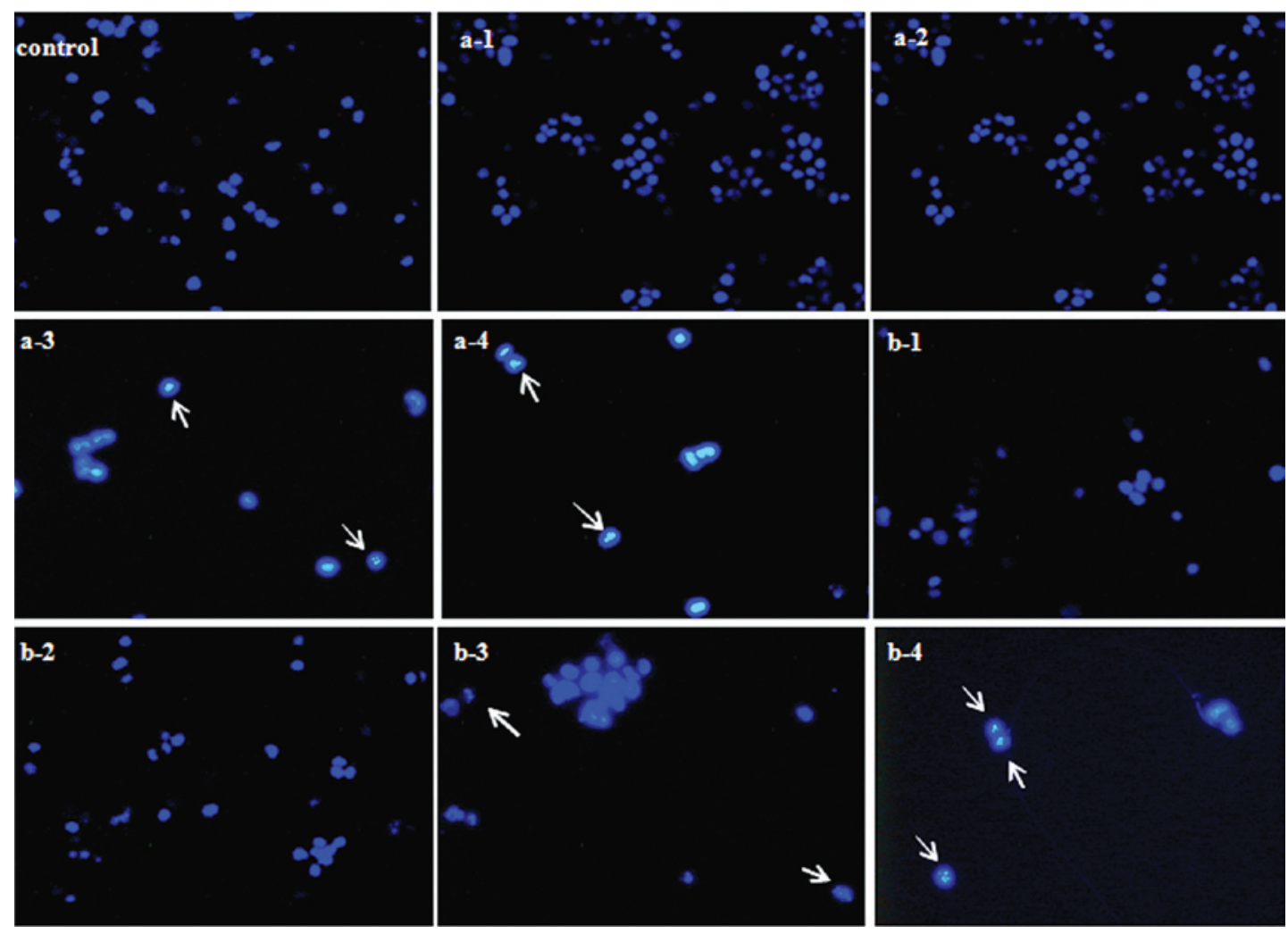

Figure 9. Nuclear morphology of DLD-1 cancer cells treated with A. kolomikta extracts. DLD-1 cells were incubated with WE-EP and WE-ES for 48 h. Extracts were produced using (a) $100^{\circ} \mathrm{C}$ and (b) $40^{\circ} \mathrm{C}$ extraction procedures. (a-1, a-2, b-1 and b-2) Treated with WE-EP; (a-3, a-4, b-3 and b-4) treated with WE-ES; (a-1, a-3, b-1 and b-3) treated with a concentration of $25 \mu \mathrm{g} / \mathrm{ml}$; (a-2, a-4, b-2, b-4) treated with a concentration of $100 \mu \mathrm{g} / \mathrm{ml}$.

metal chelators in model chemical systems (19). Furthermore, it has been reported that there is a positive significant linear relationship between antioxidant activity and total polyphenol content; polyphenols are the dominant antioxidant components in medicinal herbs (20). As our data revealed, WE-ES produced using the $100^{\circ} \mathrm{C}$ extraction procedure exhibited the highest polyphenol content (Fig. 4) and the highest SOD-like activity and DPPH radical-scavenging activity (Figs. 5 and 6). Thus, the high polyphenol content in the WE-ES fraction resulted in the high antioxidant activity. In the present study, compared to the $40^{\circ} \mathrm{C}$ extraction procedure, the $100^{\circ} \mathrm{C}$ extraction process was more effective at extracting polysaccharides and polyphenols to obtain a higher antioxidant content. This finding is similar to that in the study of Sousa et al (21).

The four extracts, WE-EP and WE-ES produced using $100^{\circ} \mathrm{C}$ and $40^{\circ} \mathrm{C}$ extraction procedures, were used for evaluating the anti-proliferative effect on DLD-1 cells. All of the fractions inhibited DLD-1 cell proliferation, and their anti-proliferative effect was in a dose-dependent manner. Furthermore, WE-ES inhibited DLD-1 cell proliferation in a time-dependent manner, compared to WE-EP, for which a slight recovery of DLD-1 cell proliferation at $48 \mathrm{~h}$ was noted. Further purification steps with DEAE Sephadex A-50 column chromatography on WE-EP (crude polysaccharide fraction) revealed that the high concentration of purified polysaccharides did not exhibit a significant anti-proliferative effect on DLD-1 cells (data not shown). This suggests that the polyphenols in the fractions conferred the main inhibitory effect on DLD-1 cell proliferation. Recently, it was reported that several plant-derived polyphenols may possess antioxi- dant, antitumor and apoptosis-inducing properties (22). For example, HL-60 cells treated with tea polyphenols were found to undergo morphological changes and chromatin fragmention characteristic of apoptosis (23). Apoptosis is the process of programmed cell death that occurs in multicellular organisms. Biochemical events lead to characteristic cell changes (morphology) and cell death. These changes include blebbing, loss of cell membrane asymmetry and attachment, cell shrinkage, nuclear fragmentation, chromatin condensation and chromosomal DNA fragmentation. Induction of apoptosis is thus considered as a strategy for cancer control. In this study, treatment with WE-EP revealed no significant changes in the percentage of apoptotic cells. In contrast, treatment with WE-ES resulted in an increase in apoptotic cells. Thus, the apoptosis-inducing effect of WE-ES on DLD-1 cells occurs in a dose-dependent manner. Furthermore, based on the results of nuclear morphological changes, nuclear fragmentation was only clearly observed when DLD-1 cells were exposed to the WE-ES fraction ( 25 and $100 \mu \mathrm{g} / \mathrm{ml}$ ) for $48 \mathrm{~h}$. Thus, these results suggest that the WE-ES fraction inhibits the proliferation of DLD-1 cells by the induction of apoptosis.

Future studies are required to purify and analyze the active components of WE-ES. Polysaccharides are reported to play an important role in the immune system, and they are currently believed to confer an antitumor effect by stimulating the host immunomodulatory activity and enhancing the host immune response to inhibit tumor growth (24). Thus, it is considered that polysaccharides have an indirect inhibitory effect on cancer cells. Thus, our future study will examine the immunomodulatory activity of WE-EP on macrophages. 
In conclusion, in this study, the water extracts from the root of A. kolomikta exhibited antioxidant activities and inhibitory effects on DLD-1 colon cancer cell proliferation. Moreover, WE-ES clearly inhibited the proliferation of DLD-1 cells by inducing apoptosis. Medicinal plant extracts are considered as non-toxic and do not cause major side effects. Actinidia kolomikta is a species of wild plant which is widely distributed throughout Asia. This initial study on the bioactivity of wild Actinidia kolomikta supports its potential use in cancer therapies or as a natural health food with antioxidant actions.

\section{Acknowledgements}

The materials were collected from their natural habitat by Dr Keo Intabon, Graduate School of Life and Environmental Sciences, University of Tsukuba, Japan.

\section{References}

1. Moskovitz J, Yim MB and Chock PB: Free radicals and disease. Arch Biochem Biophys 397: 354-359, 2002.

2. Sun J, Yao JY, Huang SX, Long X, Wang JB and Garcia EG: Antioxidant activity of polyphenol and anthocyanin extracts from fruits of Kadsura coccinea (Lem.). Food Chem 117: 276-281, 2009.

3. Mau JL, Lin HC and Song SF: Antioxidant properties of several specialty mushrooms. Food Res Int 35: 519-526, 2002.

4. Hu TJ, Wei XJ, Zhang X, Cheng FS, Shuai XH, Zhang L and Kang L: Protective effect of Potentilla anserine polysaccharide (PAP) on hydrogen peroxide induced apoptosis in murine splenic lymphocytes. Carbohydr Polym 79: 356-361, 2010.

5. PJiménez J, Arranz S, Tabernero M, Díaz-Rubio ME, Serrano J, Goñi I and Saura-Calixto F: Updated methodology to determine antioxidant capacity in plant foods, oils and beverages: Extraction, measurement and expression of results. Food Res Int 41: 274-285, 2008.

6. Hadi SM, Bhat SH, Azmi AS, Hanif S, Shamim U and Ullah MF: Oxidative breakage of cellular DNA by plant polyphenols: A putative mechanism for anticancer properties. Semin Cancer Biol 17: 370-376, 2007.

7. Du GR, Li MJ, Ma FW and Liang D: Antioxidant capacity and the relationship with polyphenol and Vitamin C in Actinidia fruits. Food Chem 113: 557-562, 2009.

8. Graham JG, Quinn ML, Fabricant DS and Farnsworth NR: Plants used against cancer - an extension of the work of Jonathan Hartwell. J Ethnopharmacol 73: 347-377, 2000.

9. Xu HS, Yao L, Sun HX and Wu YW: Chemical composition and antitumor activity of different polysaccharides from the roots of Actinidia eriantha. Carbohydr Polym 78: 316-322, 2009.
10. Xu HS, Wu YW, Xu SF, Sun HX, Chen FY and Yao L: Antitumor and immunomodulatory activity of polysaccharides from the roots of Actinidia eriantha. J Ethnopharmacol 125: 310-317, 2009.

11. Mauro M: Estimation of total carbohydrate amount in environmental samples by the phenol-sulphuric acid method assisted by multivariate calibration. Chemom Intell Lab Syst 79: 84-90, 2005.

12. Rhee SJ, Cho SY, Kim KM, Cha DS and Park HJ: A comparative study of analytical methods for alkali-soluble $\beta$-glucan in medicinal mushroom, Chaga (Inonotus obliquus). LWT-Food Sci Technol 41: 545-549, 2008.

13. Nakajima Y, Sato Y and Konishi T: Antioxidant small phenolic ingredients in Inonotus obliquus (persoon) Pilat (Chaga). Chem Pharm Bull 55: 1222-1226, 2007.

14. Yang B, Wang JS, Zhao MM, Liu Y, Wang W and Jiang YM: Identification of polysaccharides from pericarp tissues of litchi (Litchi chinensis Sonn.) fruit in relation to their antioxidant activities. Carbohydr Res 341: 634-638, 2006.

15. Zhang M, Chen HX, Huang J, Li Z, Zhu CP and Zhang SH: Effect of lycium barbarum polysaccharide on human hepatoma QGY7703 cells: inhibition of proliferation and induction of apoptosis. Life Sci 76: 2115-2124, 2005.

16. Hu HH, Zhang ZY, Lei ZF, Yang YN and Sugiura N: Comparative study of antioxidant activity and antiproliferative effect of hot water and ethanol extracts from the mushroom Inonotus obliquus. J Biosci Bioeng 107: 42-48, 2009.

17. Bennani H, Drissi A, Giton F, Kheuang L, Fiet J and Adlouni A: Antiproliferative effect of polyphenols and sterols of virgin argan oil on human prostate cancer cell lines. Cancer Detect Prev 31: 64-69, 2007.

18. Wang ZJ and Luo DH: Antioxidant activities of different fractions of polysaccharide purified from Gynostemma pentaphyllum Makino. Carbohydr Polym 68: 54-58, 2007.

19. Su XG, Duan J, Jiang YM, Shi J and Kakuda Y: Effects of soaking conditions on the antioxidant potentials of oolong tea. J Food Compos Anal 19: 348-353, 2006.

20. Cai YZ, Luo Q, Sun M and Corke H: Antioxidant activity and phenolic compounds of 112 traditional Chinese medicinal plants associated with anticancer. Life Sci 74: 2157-2184, 2004.

21. Sousa A, Ferreira ICFR, Barros L, Bento A and Alberto J: Pereira effect of solvent and extraction temperatures on the antioxidant potential of traditional stoned table olives "alcaparras". LWT-Food Sci Technol 41: 739-745, 2008.

22. Kilani-Jaziri S, Neffati A, Limem I, Boubaker J, Skandrani I, Sghair MB, Bouhlel I, Bhouri W, Mariotte AM, Ghedira K, Franca MD and Chekir-Ghedira L: Relationship correlation of antioxidant and antiproliferative capacity of Cyperus rotundus products towards K562 erythroleukemia cells. Chem-Biol Interact 181: 85-94, 2009.

23. Zhao Y, Cao J, Ma H and Liu JW: Apoptosis induced by tea polyphenols in HL-60 cells. Cancer Lett 121: 163-167, 1997.

24. Han SB, Park SK, Ahn HJ, Yoon YD, Kim YH, Lee JJ, Lee KH, Moon JS, Kim HC and Kim HM: Characterization of B cell membrane receptors of polysaccharide isolated from the root of Acanthopanax koreanum. Int Immunopharmacol 3: 683-691, 2003. 